\title{
Financial crimes and financial misdemeanours
}

by Colin Bamford

The author argues that undesirable behaviour in the financial markets has not been countered by appropriate controls.

$\mathrm{O}$ ur society has developed a wide range of measures for controlling and deterring behaviour that is felt to be undesirable. At one end of the spectrum is the public expression of disapproval by an authoritative body - the "naming and shaming" of those who are thought to have misbehaved. At the other end of the spectrum is the use of the criminal law - a highly formalised process, the outcome of which might involve the imposition of severe penalties or punishment on the offender. Between the two extremes lie a number of administrative and regulatory procedures, each of which is designed to deter or penalise the transgressor.

The argument of this paper is that, in deciding which procedure is best applied to a particular form of undesirable behaviour, we should be careful to match the selected process and its potential outcome to the nature of the transgression and to the perception of the transgression held within society at large. In the case of activity in financial markets, we have not done this. In relation to some kinds of behaviour there is a mismatch between the legislative response to the behaviour, and the view of that behaviour generally held in the community. Consequently, if juries are faced with an offence for which they think the punishment is inappropriate they may acquit the defendant even though they have little doubt that the facts alleged by the prosecution are correct.

\section{CRIME AND REGULATION}

Most people would take the view that the purpose of the criminal law is to enforce modes of behaviour that are accepted by society as obligatory. Lord Coleridge CJ said of the criminal law in $R_{v}$ Instan [1893] 1 QB 450:

“... every legal duty is founded on a moral obligation. A

legal common law duty is nothing else than the enforcing by

law of that which is a moral obligation without legal

enforcement."

The current edition of Archbold puts it more trenchantly in its very first paragraph:
"An indictment lies at common law for a breach of duty which is not a mere private injury but an outrage on the moral duties of society".

However, Parliament has not been as scrupulous as the common law in restricting criminality to those acts that imply a moral obligation. As early as the $19^{\text {th }}$ century Wright J noted in Sherras v De Rutzen [1895] 1 QB 918 that Parliament sometimes used the criminal law to control:

"... acts which ... are not criminal in any real sense, but are acts which in the public interest are prohibited under a penalty".

The use by Parliament of the criminal law as a regulatory tool, divorced from issues of ethics or morality, grew dramatically during the $20^{\text {th }}$ century and the present position is summarised by Halsbury as follows:

"A crime is frequently a moral wrong in that it amounts to
conduct which is inimical to the general moral sense of the
community ... An act may be made criminal by Parliament
simply because it is criminal, rather than civil, process which
offers the more effective means of controlling the conduct in
question" (Halsbury's Laws of England, vol 1(1), para 1).

Parliament sometimes chooses the criminal law as the appropriate process for dealing with matters which are not "criminal in any real sense" (to use the words of Wright J) but which it decides should be inhibited or prevented, for social or political purposes. Unfortunately, there does not seem to be a reasoned approach by which Parliament chooses to use the criminal process, rather than establishing a separate regulatory structure for dealing with the conduct concerned. One might suspect that the choice to criminalise an activity is often based on cost: the courts already exist, and asking them to deal with the regulation of the conduct in question will involve only a marginal cost to the taxpayer, while it would be very expensive to set up a new regulatory structure.

The judiciary has also commented on the factor of cost, although judges approach the issue from a different direction. In evidence given to the Macrory Inquiry on Regulatory Justice (Report published 2006) the Criminal 
Law Sub-Committee of the Council of HM Circuit Judges said:

"We support the view that a distinction must be drawn between matters of regulation and criminal offending. There is a pressing need to avoid expensive court time being taken up with matters that are better suited to an administrative penalty".

Parliament sometimes decides to use the criminal courts for regulatory purposes, rather than incur the expense of setting up a separate system, while the judges would prefer Parliament to set up a separate system, rather than waste their expensive time. Both approaches miss the basic point: the overriding issue is whether the criminal law is the most appropriate way of dealing with the problem, not whether it is the cheapest option.

\section{INSIDER DEALING}

In the UK, our failure to see the importance of matching the process to the offence can be illustrated by examining the history of the way in which we have treated the offence of insider dealing.

Insider dealing has been a criminal offence in the UK for almost three decades. Throughout this period, prosecutors and regulators have complained about the difficulty in obtaining convictions before the criminal courts. Between 1987 and 1997 only 13 prosecutions led to conviction (see FSA Enforcement Division - Company Lawyer, vol 28, no 2, p 43). Frustration at the low conviction rate has been compounded by the perceived leniency of judges. As one of the leading textbooks - Brenda Hannigan, Insider Dealing, $2^{\text {nd }}$ ed, p 127 - puts it:

"The difficulty in achieving a change of perception in the past decade has been compounded by the apparent unwillingness of the judiciary to treat the offence as seriously as it warrants, so that even when convictions are obtained they are often reluctant to use the full range of possible sanctions".

However, the low conviction rate and the leniency of the sentencing may not result from a culpable failure on the part of judges and juries to take the matter seriously. The explanation may be that the conduct which is sought to be controlled by the creation of the criminal offence is not such as to produce the sense of "moral outrage" that characterises criminal offences "in the real sense." Members of the public know that stock markets live on rumour and gossip and money is made or lost by participants backing hunches, often because they believe that their information is better than the information of other participants. To an outsider, it may not be obvious that the use of a particular piece of information is criminal "in the real sense".

The offence of insider dealing first reached the statute book in Part V Companies Act 1980. The precursor to the legislation was a White Paper entitled The Conduct of Company Directors (1977 Cmd 7037). The White Paper was produced by the Callaghan Government in response to a series of scandals involving the misconduct of company directors and advisers. The thrust of the White Paper was the control of the behaviour of those people, rather than any wish to regulate a particular form of activity. When dealing with the use of inside information, the White Paper said:

"Public confidence in directors and others closely associated with companies requires that such people should not use inside information to further their own interests. Furthermore, if they were to do so, they would frequently be in breach of their obligations to the companies, and would be held to be taking an unfair advantage of the people with whom they were dealing."

The rationale for criminalising insider trading by directors and advisers is to ensure that those people properly perform their fiduciary duties in order to bolster public confidence in these people. Only as a secondary point is it said that their failure to act properly may be said sometimes to involve them "taking an unfair advantage" of their trading counterparties.

The original statutory provisions were replaced in 1985 by the Company Securities (Insider Dealing) Act. Shortly afterwards, a case came before the courts, in which they were asked to consider the purpose for which the Act had been passed. Their decision had the effect of moving the statutory offence from the "moral outrage" category of criminal offences to the "controlled activity" category.

The respondent in the case was involved in negotiations for the purchase of a small listed company. He was one of several potential buyers who were talking to the company's advisers, Kleinwort Benson Limited. Ultimately, the vendors decided to sell to someone other than the respondent. As a matter of courtesy, an executive from Kleinwort Benson phoned him to tell him he had been unsuccessful, shortly before the successful transaction was announced to the Stock Exchange. As soon as his conversation finished, the respondent telephoned his brokers and bought shares in the company, expecting that the price would rise as soon as the announcement was made.

He was prosecuted under the terms of the 1985 Act, on the basis that he had "obtained" inside information and had then dealt, contrary to the terms of the Act. The only point at issue was whether the information in his possession had been "obtained". In the Crown Court, he argued successfully that the word "obtained" involved the acquisition by means of effort. He had done nothing to procure that he came into possession of the information. It had been given to him gratuitously by the company's advisers. The trial judge accepted the argument, and the respondent was acquitted.

The Attorney-General, Sir Patrick Mayhew QC, referred the matter to the Court of Appeal, and subsequently to the House of Lords (see A-G's Reference (No 1 of 1988) [1989] 1 AC 97). He made the following submission: 
"It is submitted that the purpose of the legislation was not only to provide sanctions against individuals whether or not in a fiduciary position who breached a duty of confidentiality by using information not available to the markets as a whole; it was also to preserve confidence in securities markets and to maintain their integrity and efficiency. The market has to be seen to operate fairly and if it is not investors' confidence will be seriously undermined."

The assertion is that one of the purposes of the legislation was to preserve the sanctity of the free market and, it was argued, for this reason Parliament had felt that any act that disturbed that principle, whether or not it involved moral turpitude, should be punished by the full sanction of the criminal law.

This is a most unlikely assertion. The Parliament that framed the 1980 legislation was dominated by Old Labour members, who did not regard the free market economy with the same reverence as their successors. The purpose of the legislation, as made clear by the White Paper, was to control the behaviour of company directors and advisers. It sought to criminalise activity motivated by dishonesty and greed, because such conduct invoked "moral outrage" in the wider community.

The Court of Appeal and the House of Lords, however, accepted the Attorney-General's submissions and decided, in effect, that the word "obtain" means "has". Thus, if anyone has information that he knows to be within the regulated category (irrespective of the propriety of his own conduct in bringing that about), he is precluded from dealing. Subsequent statutory amendments in the Criminal Justice Act 1993 changed the description of the offence to make it clear that no impropriety in connection with the acquisition of the information is required. The mens rea required is only the knowledge that the information is "inside information". Its use may involve no breach of any private duty. To use the terminology adopted by Lord Coleridge, there is no longer any moral obligation on which the legal duty is founded.

The position in the UK contrasts strongly with that in the United States. The United States courts began to convict insider dealers decades before their activities were criminalised in the UK. However, it has always been clear in the US that the criminal law is invoked because insider dealing is a species of fraud. It is not merely a procedural rule required to ensure smooth regulation of a market:

"There is no requirement of equality of information. Instead liability must arise from a breach of a fiduciary or other duty or from some misappropriation of information" (US $V$ Chestman 947 F.2d 551 (2nd Cir) 1991).

The position within the EU is rather more complex. The Insider Dealing Directive of 1989 (Council Directive 89/592/EEC of November 13, 1989) was implemented in the UK by Part V of the Criminal Justice Act 1993. Article 2(1) of the Directive requires Member States to prohibit: "any person who .... possesses insider information from taking advantage of that information ... by acquiring or disposing of ..."

relevant securities. This seems to follow the line taken in the UK in A-G's Reference (No 1 of 1988) that the prohibition bites when a person possesses information, and that the motives and methods that led to the acquisition are irrelevant. Certainly, that was the view taken in the UK in framing the implementing provisions of the Criminal Justice Act.

However, a recent decision of the ECJ in the Georgakis case (case C-391/04, May 10, 2007) has rejected this interpretation:

“... the purpose of the prohibition ... is to ensure equality between the contracting parties in stock-market transactions by preventing one of them who possesses inside information and who is, therefore, in an advantageous position vis-à-vis the other investors, from profiting from that information, to the detriment of the other party who is unaware of it."

In effect, the ECJ adopted the view that is taken by the US courts, that insider dealing is a way in which an insider commits a fraud on his counterparty. The evil at which the legislation is aimed is not the mere act of disturbing the integrity of the market. Indeed the court in Georgakis specifically rejected the argument that the purpose of the Directive was to maintain investor confidence in the market (see para 41 of the judgment).

The Insider Dealing Directive has been repealed by the Market Abuse Directive (Council Directive 2003/6/EC of January 28, 2003), which requires Member States to implement legislation that prohibits insider dealing as part of the wider prohibition of market abuse.

The position in the UK is confused. On the implementation of the Market Abuse Directive, it was decided to leave the criminal law provisions on insider dealing exactly as they were, and to add a new layer of regulatory provisions, also dealing with insider dealing, as required by the Market Abuse Directive. Section 118 Financial Services and Markets Act 2000 contains detailed provisions under which insider dealing is included as a form of market abuse, regulated by FSA as part of its administrative function in overseeing the operation of the financial services industry.

There are a number of technical reasons why it is desirable to give the FSA the ability to police the activity of insider trading along with other forms of behaviour that might disrupt the securities markets. The decision to leave the Criminal Law Act provisions in place, however, means that we now have two parallel forms of regulation: on the one hand, a particular type of conduct is regarded as so undesirable that it is appropriate to regulate it by the criminal law, while another form of regulation treats the same activity as a matter which is to be regulated through an administrative process. 
The UK criminal law sanction contained in the Criminal Justice Act 1993 and implementing the Insider Dealing Directive must now, following Georgakis, be taken to have as its purpose the wish to suppress fraud and the cheating of counterparties. The insider dealing provisions of the Financial Services and Markets Act, however, implement the Market Abuse Directive and have a quite different purpose, even though they are phrased in similar language.

Whatever the reason for the parallel streams of legislation, there was considerable concern that the regulatory system established by the Financial Services and Markets Act would be used as a way of side-stepping the inconvenient attitudes of the criminal courts.

This fear has turned out to be groundless. At the time when the structure of the Financial Services and Markets Act 2000 was under consideration, close thought was given to the requirements of the process by which regulatory decisions about market abuse would be reached. It was concluded that the Human Rights Act 1998 might require that proceedings under the administrative process should carry the same safeguards as would be available in criminal proceedings, given that the potential outcome in terms of penalties was of the same nature and magnitude as that in many criminal proceedings.

The response to this concern was to provide in the Act that the person accused of committing market abuse should be able to require that the matter be considered by an independent tribunal, rather than being decided by the FSA itself. The proceedings of that tribunal, the Financial Services and Markets Tribunal (FSMT), show that it will proceed in the way traditionally followed by the courts.

Of particular relevance to insider dealing is its decision of the FSMT in the Davidson case (Davidson \& Tatham v FSA, decision of the Tribunal May 16, 2006). The crucial point decided in that case was that, although the standard of proof required in regulatory proceedings under the Financial Services and Markets Act was the "civil" standard, of proof on the balance of probabilities, rather than the "criminal" standard of proof beyond reasonable doubt, the two were in practice likely to be almost indistinguishable. Where the consequences for the regulated person were as severe as they would be in criminal proceedings, the level of proof required to tip the balance of probabilities would in effect be as great as that required by the criminal standard.

The way in which insider dealing is prosecuted and penalised is far from satisfactory. It is possible to summarise its history as follows:

1. Insider dealing began life as a criminal offence, the purpose of which was to prevent or punish the dishonesty and breach of duty of those in privileged positions.

2. In 1989 the courts redefined the purpose behind the Act to say that its purpose was, in part at least, to ensure the smooth working of securities markets, rather than controlling only behaviour that was criminal "in the real sense".

3. Whether or not as a consequence of this change of official view, juries and judges have not, it seems, felt "moral outrage" when faced with the offence, and accordingly have been reluctant to convict, or to punish heavily.

4. In the Financial Services and Markets Act, the FSA was given power to deal with the matter by way of regulatory punishment. Whether or not this was structured as a deliberate attempt to avoid the perceived difficulties in obtaining convictions under the criminal law, it was assumed that this would be the result.

5. In practice, the terms of the Human Rights Act and the approach of the Financial Services and Markets Tribunal have meant that the processes under the regulatory regime are very similar to those that would apply if the criminal regime were followed.

6. From the point of view of market regulation, the efficiency of the controls has not improved.

\section{CONCLUSIONS}

The history of the offence of insider dealing is an illustration of a wider problem that we have created for ourselves. We have not drawn a distinction between those kinds of behaviour that invoke "moral outrage", and those that call for a form of administrative control. As a result, our ability to control undesirable market conduct has been inhibited because we have chosen to treat it as criminal. We have found that the invocation of the criminal law has also called up the traditional safeguards, both in terms of procedures and in terms of judicial attitudes, that defend the citizen against the erroneous application of the criminal law. The unfortunate consequence is that insider dealing and other anti-social financial behaviour remains frustratingly difficult to inhibit and control.

The answer is not to shy away from using the criminal law in financial and commercial matters, but rather to apply rigorous analysis when deciding how a particular kind of behaviour should be dealt with. In the case of insider dealing, the 1980 legislation should have isolated the factors that prompted the "moral outrage" and criminalised those, rather than looking only at the economic result of the behaviour concerned. Instead, we seem to have identified a particular outcome from behaviour that might (or might not) be generally considered reprehensible and have then made criminal any activity that results in that outcome. In other words, we have identified the symptom rather than the disease.

In future, we should give more thought to the appropriate response to each perceived evil. In particular, we should not use the criminal law unless its use resonates with the moral values of those who will form the juries that try the offence.

Colin Bamford

Barrister, 3-4 South Square 